\title{
Quality of aged shoulder from lambs fed with different oldman saltbush hay levels (Atriplex nummularia)
} Qualidade da paleta maturada de cordeiros alimentados com diferentes níveis de feno de erva-sal
(Atriplex nummularia)

\author{
Tharcilla Isabella Rodrigues Costa AlvarengaI Hirasilva Borba ${ }^{\text {II }}$ Greicy Mitzi Bezerra Moreno ${ }^{\text {III }}$ \\ Gherman Garcia Leal de Araújo ${ }^{\text {IV }}$ Juliana Lolli Malagoli de MelloII Rita de Cássia Dourado ${ }^{\text {II }}$ \\ José Carlos Barbosav ${ }^{V}$ Pedro Alves de Souza ${ }^{I I}$
}

\begin{abstract}
This study assessed the effects of different levels of oldman saltbush hay and ageing time on the physical characteristics of Santa Inês lamb meat. Sixty shoulders from 32 male lambs fed with 30, 40, 50 or 60\% oldman saltbush hay for 60 days were vacuum-packaged and stored in a refrigerator at $0 \pm$ $1{ }^{\circ} \mathrm{C}$ for 0,7 or 14 days of ageing. The shear force, cooking loss and water holding capacity were $3.06 \mathrm{~kg}^{\mathrm{cm}^{-2}}, 37.28 \%$ and $76.71 \%$, respectively, and there were no significant changed by studied factors $(P>0.05)$
\end{abstract}

Key words: cooking loss, tenderness, ageing, sheep.

\section{RESUMO}

Objetivou-se com este trabalho avaliar o efeito da inclusão de diferentes níveis de feno de erva-sal e tempo de maturação sobre as características físicas da carne de cordeiros Santa Inês. Sessenta paletas apartir de 32 cordeiros machos, alimentados com 30, 40, 50 e 60\% de feno de erva-sal por 60 dias foram embaladas a vácuo e mantidas sob refrigeração a $0 \pm 1^{\circ} \mathrm{C}$ por 0,7 e 14 dias de maturação. A força de cisalhamento, perda por cocção e capacidade de retenção de água não foram influenciados $(P>0,05)$ pelos fatores estudados, apresentando valores médios de $3,06 \mathrm{kgf} \mathrm{cm}^{-2}, 37,28 \%$ e $76,71 \%$, respectivamente.

Palavras-chave: perda por cocção, maciez, maturação, ovinos.

\section{INTRODUCTION}

The concept of meat quality is dynamic and evolves with consumer preferences. Meat quality also involves many characteristics that are strongly linked to regional traditions and cultures, thus making impossible to create a universally accepted definition. A quality product should meet the expectations of consumers, i.e., a healthy, nutritious and tasty food product (ROTA et al., 2004). To meet the requirements of the consumer market, the production sector must study the factors that influence the physical and chemical characteristics of the meat because these characteristics determine its quality and acceptability (MARTÍNEZ-CEREZO et al., 2005).

Using alternative foods for sheep finishing can minimize animal production costs and improve producer profits, which help to sustain animal production systems (MORENO et al., 2010). Due to its potential as feed, resistance to diseases, resistance to pests and ease propagation, oldman saltbush (Atriplex nummularia Lindl.) has been used in various regions as a major feed source. Atriplex is well adapted to salt and drought stress (ABOU EL NASR et al., 1996) and high levels of protein in $\boldsymbol{A}$. nummularia hay (20.2\%) (MENESES et al., 2012) and crude fiber (22.2\%) (ABU-ZANAT, 2005) may be found.

One of the best traits of saltbush is its capacity to grow and produce biomass in arid, salty environments. Once established the plant is resistant and can remain productive for several decades. High levels of protein, vitamin $\mathrm{E}$ and sulfur in oldman

IDepartamento de Zootecnia, Universidade Federal de Lavras (UFLA), 37200-000, Lavras, MG, Brasil. E-mail: tharcilla.costa@gmail.com. Autor para correspondência.

"Departamento de Tecnologia, Universidade Estadual Paulista “Júlio de Mesquita Filho” (UNESP), Jaboticabal, SP, Brasil.

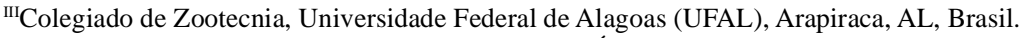

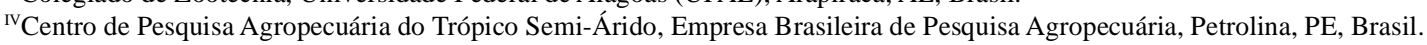

${ }^{\mathrm{v}}$ Departamento de Ciencias Exatas, UNESP, Jaboticabal, SP, Brasil. 
saltbush plants supplementold andlow-quality pastures. The main limitations of saltbush are its high salt and oxalate levels in addition to its moderate energy values and low biomass production levels. Adding saltbush to complimentary plants, such as cactus forage, is a viable solution for improving animal performance, but this solution assumes that the additional plants can grow in salty soil or be established with saltbush, which is not true. The presence of vitamin E, minerals and antioxidants can also help to improve meat quality (BEN SALEM et al., 2010).

Ageing is a meat tenderizing technique that is widely used because it is simple and efficient. In addition, meat tenderizing is a natural process driven by the enzymes in the meat and does not require the use of chemicals. Therefore, this study evaluated the physical characteristics of shoulder meat aged for 0 , 7 or 14 days from male lambs that were fed with diets containing $30,40,50$ or $60 \%$ saltbush hay.

\section{MATERIALS AND METHODS}

Sixty shoulders were used from 32 uncastrated male Santa Inês sheep raised in feedlot and fed with $30,40,50$ or $60 \%$ of oldman saltbush combined with concentrate feed at different hay:concentrate ratios. The animals were kept under experimental conditions for 60 days, which was preceded by 20 days of diet and care adaptation. Diets were formulated using the requirements recommended by the NATIONAL RESEARCH COUNCIL (2006) to achieve the nutritional requirements of lambs with $20 \mathrm{~kg}$ of body weight and a daily weight gain of $200 \mathrm{~g}$ animal $^{-1}$. Diet and mineral supplementation were provided ad libitum. The diet contained $89 \%$ DM, $12 \% \mathrm{CP}$ and $4 \mathrm{Mcal} \mathrm{kg}^{-1}$ crude energy.

After 60 days of feedlot and average 10 months of age, the animals were weighed to obtain the final body weight. The average final weights of lambs fed with $30,40,50$ or $60 \%$ saltbush hay were $36.31 \pm 3.41, \quad 34.88 \pm 5.07, \quad 32.75 \pm 4.24$ and $31.06 \pm 4.40 \mathrm{~kg}$, respectively. The animals were held in fasting for 18 hours and slaughtered by electric stunning (330V about 12 seconds) followed by bleeding. The carcasses were refrigerated at $5 \pm 2^{\circ} \mathrm{C}$ for 24 hours. At 24 hours post mortem, the shoulder muscles were collected using a scalpel, labeled, vacuum-packed and stored in refrigeration at $0 \pm 1{ }^{\circ} \mathrm{C}$ for 7 and 14 days. For day 0 (without ageing), the shoulders were frozen at $-18^{\circ} \mathrm{C}$ immediately after obtaining the meat cuts.

After ageing the shoulder muscles, $\mathrm{pH}$ was measured using a digital $\mathrm{pH}$ meter connected to a penetrating probe. Color was measured using a Minolta CR-300 colorimeter (diffuse illumination $/ 0^{\circ}$ viewing angle, specular component included) and the CIELAB system ( $L^{*}$, lightness; $a^{*}$, redness; and $b^{*}$, yellowness) calibrated to a white standard.

Water-holding capacity was calculated using the method described by HAMM (1961) with slight modifications. Meat samples weighing $500 \pm 20 \mathrm{mg}$ were placed on filter paper between two acrylic plates, and a $10 \mathrm{~kg}$ weight was placed on top of the plates for 5 minutes. The results are expressed as percentages compared to initial weight as follows: $\mathrm{WHC}=100-\left(\left(\mathrm{W}_{\mathrm{i}}-\mathrm{W}_{\mathrm{f}}\right) / \mathrm{W}_{\mathrm{i}}^{*} 100\right)$, where $\mathrm{WHC}$ is the water-holding capacity, $\mathrm{W}_{\mathrm{i}}$ is the initial weight, and $\mathrm{W}_{\mathrm{f}}$ is the final weight.

To measure cooking loss, the samples were weighed and cooked in an industrial oven preheated to $175^{\circ} \mathrm{C}$ until the internal temperature of the samples reached $72^{\circ} \mathrm{C}$. The samples were then removed from the oven, cooled at room temperature and weighed again. Cooking loss was calculated by the difference between the initial weight and final weight of the cooked samples. Subsequently, subsamples were taken from the cooked samples parallel to the muscular fibers while avoided connective tissue and fat. Samples were cut perpendicular to the muscular fibers. The heights and widths of the subsamples were measured to calculate the area in $\mathrm{cm}^{2}$, and the shear forces of the subsamples were measured using a TA-TX2 Texture Analyzer connected to a WarnerBratzler device. The data were expressed in $\mathrm{kgf} \mathrm{cm}^{-2}$.

Data were analysed using the AGROESTAT program (BARBOSA \& MALDONADO JR, 2010). The experimental design was a $3 \times 4$ factorial design (three ageing times and four levels of saltbush hay), with four shoulders per treatment to SF and CL and five shoulders per treatment to $\mathrm{pH}$, WHC and colour measurements. Analysis of variance and comparisons of the averages using Tukey's test at a 5\% probability level. Polynomial regression analysis was used to evaluate the effect of the saltbush hay levels.

\section{RESULTS AND DISCUSSION}

There was no interaction between the saltbush hay level and ageing $(\mathrm{P}>0.05)$ for $\mathrm{pH}, a^{*}$ and $b^{*}$ values (Table 1 ). Shoulders aged for 14 days had lower $\mathrm{pH}$ values (5.66) than aged for 7 days (5.78). The average $\mathrm{pH}$ values were higher $(\mathrm{P}<0.05)$ in meat from animals fed with $60 \%$ saltbush hay (5.76) but did not differ from the $\mathrm{pH}$ values of meat from animals fed with 30 (5.73) or 50\% (5.69) saltbush hay diets. According PARDI et al. (2001), pH values 
Table 1 - $\mathrm{pH}$, lightness $\left(L^{*}\right)$, redness $\left(a^{*}\right)$ and yellowness $\left(b^{*}\right)$ values of aged shoulders from lambs fed with different saltbush hay levels.

\begin{tabular}{lllll}
\hline Saltbush hay $(\%)$ & $\mathrm{pH}$ & $L^{*}$ & $a^{*}$ & $b^{*}$ \\
\hline 30 & $5.73 \mathrm{ab}$ & 43.28 & $17.84 \mathrm{~b}$ & 5.16 \\
40 & $5.67 \mathrm{~b}$ & 43.92 & $18.73 \mathrm{a}$ & 5.75 \\
50 & $5.69 \mathrm{ab}$ & 43.75 & $18.96 \mathrm{a}$ & 5.90 \\
60 & $5.76 \mathrm{a}$ & 44.38 & $18.60 \mathrm{ab}$ & 5.77 \\
F-test & 3.15 & 1.83 & 4.71 & 2.61 \\
$\mathrm{P}$ & 0.0333 & 0.1545 & 0.0058 & 0.0620 \\
Ageing (days) & & & $5.08 \mathrm{~b}$ \\
0 & $5.71 \mathrm{ab}$ & 44.63 & $18.14 \mathrm{~b}$ & $5.22 \mathrm{~b}$ \\
7 & $5.78 \mathrm{a}$ & 43.52 & $18.33 \mathrm{~b}$ & $6.64 \mathrm{a}$ \\
14 & $5.66 \mathrm{~b}$ & 43.36 & $19.11 \mathrm{a}$ & 23.63 \\
F-test & 8.08 & 5.62 & 7.02 & 0.0001 \\
P & 0.0009 & 0.0064 & 0.0021 & 1.12 \\
Interaction (S x A) & & & & 0.3630 \\
F-test & 2.07 & 2.87 & 0.77 & 14.02 \\
P & 0.0738 & 0.0179 & 0.5985 & 4.68 \\
CV $(\%)$ & 1.59 & 2.97 & & \\
\hline
\end{tabular}

Within the same factor, averages followed by distinct letters differ according to Tukey's test $(\mathrm{P}<0.05)$. $\mathrm{P}=\mathrm{probability}$. $\mathrm{CV}=$ coefficient of variation.

ranging from 5.5 to 5.8 are normal 24 hours after slaughter. In this study, the $\mathrm{pH}$ values of the shoulder muscles were within this range GONÇALVES et al. (2004) also found effect in $\mathrm{pH}$ under ageing effect and related this with the glycolysis and accumulation of lactic acid after animal slaughter. There was an interaction $(\mathrm{P}<0.05)$ between saltbush hay level and ageing for lightness value $\left(L^{*}\right)$ (Table 2$)$. Meat from the lambs fed with $60 \%$ saltbush hay had a higher lightness $(\mathrm{P}<0.05)$ when the shoulders were aged for 14 days than shoulders aged for 7 days. Differences in the lightness values were not detected for the other levels of saltbush hay. Shoulders aged for 14 days from lambs fed with $60 \%$ saltbush hay showed the lightness values higher than 30 and 50\% saltbush hay but were similar to the $40 \%$ saltbush hay. PEARCE et al. (2005) found increase from 2.4 to $6.3 \mathrm{mg} \mathrm{kg}^{-1} \mathrm{LL}$ muscle alpha-tocopherol among lambs fed with control and saltbush diet, respectively. The $* L$ values is a positive effect and the plausible explanation is due to the saltbush increase in the vitamin E levels on muscle, which improve the color stability (PEARCE et al., 2010). The lightness is an objective analysis that may be used to predict final meat quality when evaluated together with other parameters. BONAGURIO et al. (2003) reported that meat lightness decreases when the slaughter weight of sheep increases. Similar to this study, the lightest animals were from feeding with $60 \%$ saltbush hay and had the highest lightness values when the meat was aged for 14 days. MORENO et al. (2010) showed that the effect of including saltbush hay in the slaughter weight decreased when the saltbush hay level was increased in diet of the animals in the present study $(36.31 \pm 3.41,34.88 \pm 5.07,32.75 \pm 4.24$ and $31.06 \pm 4.40 \mathrm{~kg}$ of the slaughter weight for 30,40 , 50 and $60 \%$ saltbush hay, respectively). ZEOLA et al. (2007) reported that the ageing influences $(P<0.05)$ the lightness and redness values but does not affect yellowness values.

Shoulders aged for 14 days had higher $(\mathrm{P}<0.05)$ redness values $\left(a^{*}\right)$ than those aged for 7 days and unaged. The average redness values $\left(a^{*}\right)$ for the 40 and $50 \%$ saltbush hay samples differed $(\mathrm{P}<0.05)$ from the $30 \%$ saltbush samples but were similar to the redness values of the $60 \%$ saltbush samples. The higher redness level in meat is considered a positive effect for the consumers. The yellowness values $\left(b^{*}\right)$ did not differ $(\mathrm{P}>0.05)$ among the saltbush hay levels but was different among ageing time. Shoulders aged for 14 days had higher (6.64) yellowness value $\left(b^{*}\right)$ than those aged for 7 days (5.22) and unaged (5.08). PEARCE et al. (2005) identified a behavior that was similar to these parameters when they evaluated meat from lambs fed with saltbush pasture. In addition, these authors concluded that consumers prefer redder meat and that increased yellowness $\left(b^{*}\right)$ of meat may reduce its acceptance by consumers. Including saltbush hay improved meat color by making it redder without altering the yellowness, which suggests that saltbush hay is a good option for producing meat that meets consumer acceptance standards.

Ciência Rural, v.44, n.12, dez, 2014. 
Table 2 - Interaction among saltbush hay level and ageing time for lightness in meat lamb.

\begin{tabular}{|c|c|c|c|c|c|c|}
\hline \multirow{2}{*}{ Ageing (days) } & \multicolumn{4}{|c|}{ 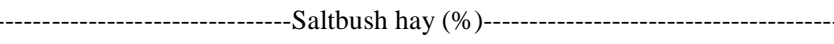 } & \multirow{2}{*}{ F-test } & \multirow{2}{*}{$\mathrm{P}$} \\
\hline & 30 & 40 & 50 & 60 & & \\
\hline 0 & $43.50 \mathrm{~A} \mathrm{a}$ & $45.05 \mathrm{~A} \mathrm{a}$ & $44.50 \mathrm{~A} \mathrm{a}$ & $45.45 \mathrm{~A} \mathrm{a}$ & 2.11 & 0.1107 \\
\hline 7 & $43.85 \mathrm{~A} \mathrm{a}$ & $43.61 \mathrm{~A} \mathrm{a}$ & $44.03 \mathrm{~A} \mathrm{a}$ & $42.58 \mathrm{~A} \mathrm{~b}$ & 1.24 & 0.3042 \\
\hline 14 & $42.50 \mathrm{~B} \mathrm{a}$ & $43.11 \mathrm{AB}$ a & $42.72 \mathrm{~B} \mathrm{a}$ & $45.12 \mathrm{~A} \mathrm{a}$ & 4.22 & 0.0100 \\
\hline F-test & 1.44 & 3.00 & 2.51 & 7.30 & & \\
\hline $\mathrm{P}$ & 0.2477 & 0.0592 & 0.0922 & 0.0017 & & \\
\hline
\end{tabular}

For a given factor, averages followed by distinct lowercase letters in the column are different according to Tukey's test $(\mathrm{P}<0.05)$. For a given factor, averages followed by similar capital letters in the row are not different from each other according to Tukey's test. $\mathrm{P}=$ probability.

There was no significant interaction $(\mathrm{P}>0.05)$ among ageing and saltbush hay levels for shear force (SF), cooking loss (CL) and water holding capacity (WHC) of the lamb shoulder (Table 3). These variables were not influenced $(\mathrm{P}>0.05)$ by saltbush hay level or ageing time, with average values of $3.06 \mathrm{kgf}$ $\mathrm{cm}^{-2}, 37.28 \%$ and $76.71 \%$ for SF, CL and WHC, respectively. GONÇALVES et al. (2004) also did not find a significant difference in CL and SF for 1, 3, 7 and 14 days of ageing at $2^{\circ} \mathrm{C}$ for the lamb longissimus muscle, and they explained that the decrease in SF may not have been observed because the SF results on the first day post mortem were already sufficiently low (3.78kgf). The results reported by GONÇALVES et al. (2004) were consistent with the results identified in this study which the average values for SF were $3.44,3.11$ and $2.64 \mathrm{kgf} \mathrm{cm}^{-2}$ for 0,7 and 14 days of

Table 3 - Shear force (SF), cooking loss (CL) and water-holding capacity (WHC) of aged shoulders from lambs fed with different saltbush hay levels.

\begin{tabular}{lcll}
\hline Saltbush hay (\%) & $\mathrm{SF}\left(\mathrm{kgf} \mathrm{cm}^{-2}\right)$ & $\mathrm{CL}(\%)$ & WHC $(\%)$ \\
\hline 30 & 2.74 & 36.16 & 76.09 \\
40 & 3.21 & 37.46 & 76.13 \\
50 & 2.81 & 37.80 & 77.18 \\
60 & 3.50 & 37.72 & 77.42 \\
F-test & 1.04 & 0.15 & 0.89 \\
P & 0.3866 & 0.9319 & 0.4534 \\
Ageing (days) & & & \\
0 & 3.44 & 36.33 & 76.57 \\
7 & 3.11 & 39.03 & 76.55 \\
14 & 2.64 & 36.48 & 77.00 \\
F-test & 1.78 & 0.76 & 0.16 \\
P & 0.1832 & 0.4732 & 0.8523 \\
Interaction (S x A) & & & \\
F-test & 0.69 & 0.50 & 0.70 \\
P & 0.6552 & 0.8017 & 0.6487 \\
CV (\%) & 39.54 & 18.59 & 12.23 \\
\hline
\end{tabular}

$\mathrm{P}=$ probability. $\mathrm{CV}=$ coefficient of variation. ageing, respectively. WHEELER \& KOOHMARAIE (1999) found slightly lower reduction in shear force from 1 to $10 \mathrm{~d}$ and assign this due to the fact that the control psoas major muscle was already so tender that there was little room for improvement.

ZEOLA et al. (2007) analyzed the effects of different ageing times and calcium chloride injection on the color, WHC and tenderness of lamb biceps femoris, longissimus and triceps brachii muscles. They found that ageing affects the reduction of WHC of the triceps brachii muscles but not of the biceps femoris and longissimus muscles, even though the SF values of the biceps femoris and longissimus muscles are affected by ageing. Although in this study there was not effect of the saltbush in WHC, PEARCE et al. (2010) affirm that the high level of salt in saltbush may be responsible for the increase in hydration status observed in sheep fed with saltbush and high vitamin $\mathrm{E}$ concentrations in muscle may aid in the retention of water, but further research are necessary to explain this effect.

Table 4 shows the regression equation for the effects of 30, 40, 50 and $60 \%$ saltbush hay in lamb diets. Shoulders unaged had a linear $(\mathrm{P}<0.05)$ increase in the results for lightness $\left(L^{*}\right)$ and yellowness $\left(b^{*}\right)$, with slopes of 0.0530 and 0.0356 , respectively. A quadratic behavior was observed for $\mathrm{pH}$, with a minimum value at $43.9 \%$ saltbush hay in unaged meat. Shoulders aged for 7 days had a quadratic behavior for redness $(a *)$, with a maximum at $47.95 \%$ of saltbush hay. A cubic effect $(\mathrm{P}<0.05)$ was observed for the $\mathrm{pH}$, tenderness and overall quality of the product, with estimated maximums at 36,55 and $54 \%$ saltbush hay, respectively, and minimums at 51, 39 and $38 \%$ saltbush hay, respectively. Shoulders aged for 14 days had a positive linear effect $(\mathrm{P}=0.0063)$ on lightness $\left(L^{*}\right)$, with a slope of 0.0744 .

\section{CONCLUSION}

There were no detrimental effects of increasing saltbush hay until $60 \%$ level in the diet of 
Table 4 - Regression analysis of the variables revealed significant effects as a function of the saltbush hay levels ( $30,40,50$ and $60 \%)$.

\begin{tabular}{|c|c|c|c|c|}
\hline Ageing (days) & Variable & Regression Equation & $\mathrm{P}$ & $\mathrm{R}^{2}$ \\
\hline \multirow{3}{*}{0} & $\mathrm{pH}$ & $Y=6.6465-0.0439 x+0.0005 x^{2}$ & $*$ & 0.61 \\
\hline & $L^{*}$ & $Y=42.2462+0.0530 x$ & $*$ & 0.65 \\
\hline & $b^{*}$ & $Y=3.4834+0.0356 x$ & $*$ & 0.65 \\
\hline \multirow{2}{*}{7} & $a^{*}$ & $Y=7.5420+0.4795 x-0.0050 x^{2}$ & $*$ & 0.99 \\
\hline & $\mathrm{pH}$ & $Y=0.3900+0.3989 x-0.0095 x^{2}+0.00007 x^{3}$ & $*$ & 1.00 \\
\hline 14 & $L^{*}$ & $Y=40.0179+0.0744 x$ & $* *$ & 0.65 \\
\hline
\end{tabular}

$L^{*}=$ lightness. $b^{*}=$ yellowness. $a *=$ redness. $* \mathrm{P}<0.05 . * * \mathrm{P}<0.01 . \mathrm{Y}=$ variable. $\mathrm{x}=$ saltbush hay level.

lambs, and there was improvement in the lightness with $60 \%$ saltbush hay level in meat aged for 14 days.

\section{ACKNOWLEDGEMENTS}

This work was financially supported by 'Fundação de Amparo à Pesquisa do Estado de São Paulo' (FAPESP) and 'Banco Nacional do Desenvolvimento' (BNDES).

\section{COMITÊ DE ÉTICA E BIOSSEGURANÇA} Ética é: 008403-08.

Protocolo da aprovação do trabalho pelo Comitê de

\section{REFERENCES}

ABOU EL NASR, H.M. et al. Value of processed saltbush and acacia shrubs as sheep fodders under the arid conditions of Egypt. Small Ruminant Research, v.24, p.15-20, 1996. Available from: <http://www.sciencedirect.com/science/article/pii/ S0921448896009327>. Accessed: Mar. 22, 2014. doi: 10.1016/ S0921-4488(96)00932-7.

ABU-ZANAT, M.M.W. Voluntary intake and digestibility of saltbush by sheep. Asian-Australian Journal Animal Science, v.18, n.2, p.214-220, 2005. Available from: <http:// www2.ju.edu.jo/sites/Academic/mahfouz/Lists/Published\%20 Research/Attachments/4/Voluntary\%20Intake\%20and\%20 Digestibility2005.pdf>. Accessed: Mar. 22, 2014.

BARBOSA, J.C.; MALDONADO JR, W. AgroEstat. Sistema para análises estatísticas de ensaios agronômicos. Versao 1.0. Universidade Estadual Paulista "Júlio de Mesquita Filho" - Faculdade de Ciências Agrárias e Veterinárias, Jaboticabal, Brasil, 2010.

BEN SALEM, H. et al. Potential use of oldman saltbush (Atriplex nummularia Lindl.) in sheep and goat feeding. Small Ruminant Research, v.91, p.13-28, 2010. Available from: <http://www. sciencedirect.com/science/article/pii/S0921448810000246>. Accessed: Out. 15, 2011. doi: 10.1016/j.smallrumres.2009.10.017.

BONAGURIO, S. et al. Qualidade da carne de cordeiros Santa Ines puros e mesticos com Texel abatidos com diferentes pesos. Revista Brasileira de Zootecnia, v.32, n.6, p.1981-1991, 2003. Available from: <http://www.scielo.br/pdf/rbz/v32n6s2/20971. pdf $>$ Accessed: Dec. 08, 2011. doi: 10.1590/S151635982003000800023
GONÇALVES, L.A.G. et al. Efeitos do sexo e do tempo de maturação sobre a qualidade da carne ovina. Ciência e Tecnologia de Alimentos, v.24, n.3, p.459-467, 2004. Available from: <http:// www.scielo.br/pdf/cta/v24n3/21943.pdf>. Accessed: Jan. 15, 2012. doi: 10.1590/S0101-20612004000300027.

HAMM, R. Biochemistry of meat hydration. Advanceds in Food Research, v.10, p.335-443, 1961. Available from: <http://www. sciencedirect.com/science/article/pii/S006526280860141X>. Accessed: Jan. 10, 2012. doi: 10.1016/S0065-2628 (08) 60141-X.

MARTÍNEZ-CEREZO, S. et al. Breed, slaughter weight and ageing time effects on consumer appraisal of three muscles of lamb. Meat Science, v.69, p.795-805, 2005. Available from: <http:// www.sciencedirect.com/science/article/pii/S0309174004002955>. Accessed: Feb. 05, 2012. doi: 10.1016/j.meatsci.2004.11.013.

MENESES, R. et al. Evaluating the use of Atriplex nummularia hay on feed intake, growth, and carcass characteristics of creole kids. Chilean Journal of Agricultural Research, v.72, n.1, p.74-79, 2012. Available from: $<$ http://www.scielo.cl/scielo.php?script=sci_ arttext\&pid=S0718-58392012000100012>. Accessed: Mar. 22, 2014. doi: 10.4067/S0718-58392012000100012.

MORENO, G.M.B. et al. Desempenho de cordeiros Santa Inês alimentados com níveis de feno de erva-sal e concentrado. In: Reunião Anual da Sociedade Brasileira de Zootecnia, 47., 2010, Salvador, BA. Anais... Salvador: Sociedade Brasileira de Zootecnia, 2010. (CD-ROM).

NATIONAL RESEARCH COUNCIL (NRC). Nutrient requirement of small ruminants. Washington, DC, 2006. 362p.

PARDI, M.C. et al. Ciência, higiene e tecnologia da carne. 2.ed. Goiânia: UFG, 2001. 623p.

PEARCE, K.L. et al. Plasma and tissue $\alpha$-tocopherol concentrations and meat colour stability in sheep grazing saltbush (Atriplex spp.). Australian Journal of Agricultural Research, v.56, p.663-672, 2005. Available from: <http://www.publish.csiro. au/paper/AR05001.htm>. Accessed: Mar. 15, 2012. doi: 10.1071/ AR05001.

PEARCE, K.L. et al. The role of saltbush-based pasture systems for the production of high quality sheep and goat meat. Small Ruminant Research, v.91, p.29-38, 2010. Available from: <http://www.sciencedirect.com/science/ article/pii/S0921448810000258\#>. Accessed: Feb. 20, 2014. doi:10.1016/j.smallrumres.2009.10.018. 
ROTA, E.L. et al. Efeitos do cruzamento de carneiros da raça Texel com ovelhas Corriedale e Ideal sobre a qualidade da carne. Revista brasileira de Agrociência, v.10, n.4, p.487-491, 2004. Available from: <http://www.ufpel.tche.br/faem/agrociencia/ v10n4/artigo14.pdf>. Accessed: Oct. 15, 2011.

WHEELER. T.L.; KOOHMARAIE, M. The extent of proteolysis is independent of sarcomere length in lamb longissimus and psoas major. Journal of Animal Science, v.77, p.2444-2451,
1999. Available from: <http://www.journalofanimalscience.org/ content/77/9/2444.full.pdf>. Accessed: Mar. 22, 2014.

ZEOLA, N.M.B. et al. Capacidade de retenção de agua e maciez da carne de cordeiro maturada e injetada com cloreto de calcio. Arquivo Brasileiro de Medicina Veterinária e Zootecnia, v.59, n.4, p.1058-1066, 2007. Available from: <http://www.scielo.br/ pdf/abmvz/v59n4/36.pdf>. Accessed: Oct. 16, 2011. doi: 10.1590/ S0102-09352007000400036. 